\title{
FORMATION OF THE THREE-LAYERED STRUCTURE OF THE AMERY ICE SHELF, ANTARGTICA
}

\author{
By Gorow Wakahama \\ (Institute of Low Temperature Science, Hokkaido University, Kita I9 Nishi 8, Kita-ku, \\ Sapporo, Japan o6o) \\ and W. F. BudD \\ (Antarctic Division, Department of Science, 568 St Kilda Road, Melbourne, Victoria 3oo4, \\ Australia)
}

Abstract. Extensive glaciological studies on the Amery Ice Shelf have been conducted since 1962 by the Australian National Antarctic Research Expeditions (ANARE). Deep core drilling to the depth of $3 \mathrm{IO} \mathrm{m}$ was carried out in I 968 at the site G I on the shelf in order to obtain the vertical ice temperature distribution and to collect ice cores over the whole depth of the bore hole. General core analyses have been conducted since r 970 under an AustraliaJapan Cooperative Project in order to clarify the structure of the ice shelf in connection with its flow.

It was found through these analyses that the Amery Ice Shelf consists of three layers of different origin, which are denoted the top, middle, and bottom layers. The top layer is formed by the in situ accumulation of snow on the shelf, the middle layer is glacier ice flowing from the Lambert Glacier, originating far inland on the Antarctic ice sheet, and the bottom layer is developed by the freezing of sea-water at the bottom surface. Numerical calculations were made of the formation processes of the three-layered structure of the ice shelf, in which the accumulation and the densification of snow at the top surface, the straining of the shelf, and the freezing of sea-water at the bottom surface were taken into account.

The thicknesses of the top and the bottom layers at site G I obtained from the present calculations agree well with those obtained from the core analyses. The freezing rate of seawater at the bottom surface of the ice shelf estimated from the temperature profile is approximately $0.5 \mathrm{~m} \mathrm{a}^{-1}$. This considerable growth of frozen sea-water at the base of the ice shelf results in water flowing out from under the ice shelf being more saline and warmer than that flowing in.

\section{DISCUSSION}

C. F. Raymond: Is there an explanation of the zone of coarse-grained ice lying just above the I $00 \mathrm{~m}$ transition boundary?

W. F. BudD: Yes, the upper transition layer corresponds to the transition region between the ablation areas on the Lambert Glacier and the accumulation area on the Amery Ice Shelf. Large melt pools form on the Lambert Glacier in summer. These freeze in winter. This could give rise to the large crystals.

J. W. Glen: Is the small-grained ice at the top of the middle layer consistent with the top of the ablation zone of the Lambert Glacier?

R. LeB. Hooke: The fine ice at the top of the middle layer is very similar to superimposed ice on the Barnes Ice Cap. This could have formed on the lower reaches of the Lambert Glacier where some ablation occurs. 
I was interested in the systematic increase in number of poles in the fabric with increase in grain size. This also occurs in deformed superimposed ice at the margin of the Barnes Ice Cap, at about the same temperature. In the Barnes situation, stress inhomogeneities probably cannot be responsible for the change in fabric because the changes occur over a depth interval of only a few meters, and the bands of coarse ice alternate with bands of finer ice.

BuDD: The small grain size is correct for superimposed ice.

As regards the crystal orientations in the Lambert ice section, the fabrics reflect the past stress history of the ice over long periods of time during which it has passed through different situations with resultant overprinting. This seems to be consistent with the observed strainrates along the line of flow.

As regards the Barnes Ice Cap, it is difficult to comment without knowing the past stress or strain histories of the layers. If the layers have different fabric patterns then they probably have different flow properties and may have had different deformation or annealing histories.

RAYMOND: Could you clarify the nature of the $c$-axis fabric of the frozen sea-water in the lower layer. This is interesting, since you are proposing that freezing takes place by removal of heat into the water rather than through the ice as occurs in formation of sea ice. The $c$-axis fabric might be affected by this difference.

BudD: Slow-freezing fresh-water ice generally has $c$-axis vertical in contrast to sea ice with $c$-axis horizontal. Palosuo (I96I) states that a salinity of about 0.6 parts per thousand separates these two situations. The low salinity of the Amery ice suggests that it was formed from water of lower salinity than this.

G. DE Q. Robin: How does water freeze on the bottom of the ice shelf?

BudD: The following picture has developed. The Soviet Antarctic Expedition soundings in front of the ice shelf for salinity, temperature and depth suggest a clockwise circulation in front of and under the shelf. Melting takes place at the outer edge of the shelf. This cools the seawater, which is already near the freezing point, and liberates comparatively fresh water which, because of the lower salinity, is less dense. (At these temperatures salinity rather than temperature primarily controls the density.) This cool, fresh water mixes with the sea-water but remains near the surface as the stream moves further under the shelf. Here a small amount of heat flows into the ice shelf along the small temperature gradient. This is enough to initiate freezing. This freezing liberates salt which tends to make the boundary-layer water more saline and therefore more dense. This sets up a vertical circulation which keeps the process going and removes most of the latent heat liberated by freezing. Because freezing predominates over melting, the water becomes warmer and more saline. Thus, the water on the western side coming out from under the shelf is more saline and warmer than the water on the eastern side, especially at the lower levels. This is confirmed by the Soviet soundings. In addition the magnitudes correspond to those calculated from the freezing and melting under the shelf, as deduced from the analysis of the particle paths computed for the ice shelf in conjunction with the measured ice thickness.

W. S. B. Paterson: What is the explanation of the zero value of the oxygen isotope ratio at a depth of about $260 \mathrm{~m}$ ?

Budd: The zero $\delta^{18} \mathrm{O}$ value at $260 \mathrm{~m}$ refers to a layer about $0.5 \mathrm{~m}$ thick and is believed to be from sea-water frozen in a bottom crevasse formed near the hinge line of the Lambert GlacierAmery Ice Shelf boundary.

Paterson: From the oxygen isotope profile, there did not appear to be any ice from the last glaciation. Has such ice been removed by bottom melting in the Lambert Glacier? 
BuDd: There has been considerable longitudinal strain from the inland ice sheet to the Lambert Glacier. This would thin the cold isotope layer substantially so that the considerable melt expected while travelling down the Lambert could then remove it.

\title{
REFERENCE
}

Palosuo, E. 1961. Crystal structure of brackish and fresh-water ice. Union Géodésique et Géophysique Internationale. Association Internationale d'Hydrologie Scientifique. Assemblée générale de Helsinki, 25-7-6-8 196o. Commission des Neiges et Glaces, p. 9-14.

\section{THERMO-PHYSIGAL CHARACTERISTICS OF GLACIERS- TOWARD A RATIONAL CLASSIFICATION}

\author{
By Maynard M. Miller
}

(Department of Geology, Michigan State University, East Lansing, Michigan 48823, U.S.A. and Foundation for Glacier and Environmental Research, Pacific Science Center, Seattle, Washington 98 iog, U.S.A.)

Abstract. Forty years ago, Ahlmann considered the thermo-physical character of ice masses as a basis for differentiating glaciers into two broad geophysical groups: (I) polar and (2) temperate. About the same time, Lagally sub-divided glaciers into corresponding thermodynamic categories: (I) kalt and (2) warmen. By this it was understood that the temperature of a polar, or "cold", glacier was perennially sub-freezing throughout, except for a shallow surface zone which might be warmed for a few centimeters each year by seasonal atmospheric variations. Conversely, in a temperate, or "warm", glacier, the temperature below a recurring winter chill layer was consistently at the pressure melting point. As these terms are thermodynamic in connotation, glaciers of the polar type may exist at relatively low altitudes if their elevations are sufficiently great. Temperate glaciers may be found even above the Arctic Circle at elevations low enough that chilling conditions are not induced by the lapse rate.

In these distinctions, it is implied that regardless of geographical location a glacier's mean internal temperature represents an identifiable characteristic which can be shown critically to affect the mass and liquid balance of ice masses and significantly to relate climatic influences to glacier regimes. The importance of these implications, and the fact that they are based on a gross, sometimes changing, and always difficult to measure, thermo-physical characteristic, makes some explicit terminology desirable.

To some extent Ahlmann addressed this problem by introducing a subordinate classification, sub-polar glaciers. In these, the penetration of seasonal warmth involved only a shallow surface layer at $0^{\circ} \mathrm{C}$, but still to a depth substantially greater than the superficial warming experienced in summer on polar glaciers. Lagally also recognized an intermediate type which he called "transitional", characterized by a relatively deep penetration of $\mathrm{o}^{\circ} \mathrm{C}$ englacial conditions during the summer. These pioneering efforts reflect Ahlmann's experience with glaciers in the high Arctic and Lagally's with the Alpine glaciers of southern Europe. Although some confusion has resulted from alternate application of these different terms, both definitions can be useful. Further to refine the classification, a modified terminology is suggested by the writer. This involves introducing a fourth category, substituting the term sub-temperate for Lagally's "transitional" type on the basis that it is etymologically more consistent with the 